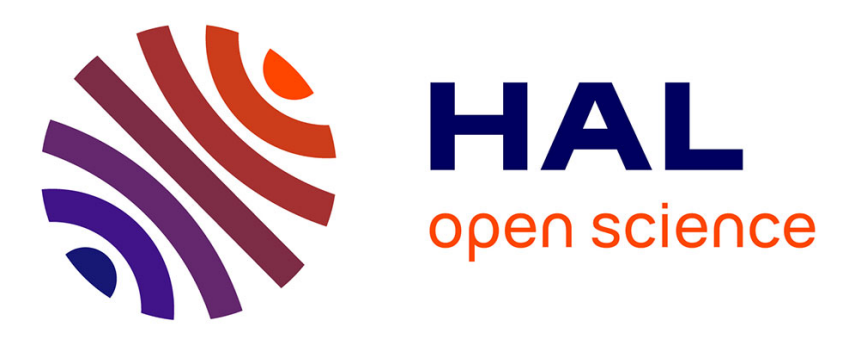

\title{
Use of Accuracy Profile Procedure to Validate a Real-Time PCR Method to Quantify Bacteria in Feces
}

Manuel J Saint-Cyr, Agnès Perrin-Guyomard, Paméla Houée, Maleck V. Vasseur, Michel Laurentie

\section{- To cite this version:}

Manuel J Saint-Cyr, Agnès Perrin-Guyomard, Paméla Houée, Maleck V. Vasseur, Michel Laurentie. Use of Accuracy Profile Procedure to Validate a Real-Time PCR Method to Quantify Bacteria in Feces. Journal of AOAC INTERNATIONAL, 2014, 97 (2), pp.1-7. 10.5740/jaoacint.13-310 . hal-00939269

\section{HAL Id: hal-00939269 https://hal.science/hal-00939269}

Submitted on 30 Jan 2014

HAL is a multi-disciplinary open access archive for the deposit and dissemination of scientific research documents, whether they are published or not. The documents may come from teaching and research institutions in France or abroad, or from public or private research centers.
L'archive ouverte pluridisciplinaire HAL, est destinée au dépôt et à la diffusion de documents scientifiques de niveau recherche, publiés ou non, émanant des établissements d'enseignement et de recherche français ou étrangers, des laboratoires publics ou privés. 


\title{
Use of Accuracy Profile Procedure to Validate a Real-Time PCR Method to Quantify Bacteria in Feces
}

\author{
Manuel J. Saint-Cyr, Agnès Perrin-Guyomard, and Paméla Houée \\ Anses, Fougères Laboratory, Antibiotics, Biocides, Residues and Resistance Unit, Fougères, France \\ MaleK V. VASSeur \\ Anses, Fougères Laboratory, Antibiotics, Biocides, Residues and Resistance Unit, Fougères, France; INRA, UMR 1331, Toxalim, \\ Pharmacokinetics, Pharmacodynamics and Modelisation Team, Toulouse, France; Anses, Fougères Laboratory, Scientific Support \\ Unit, Fougères, France \\ Michel Laurentie \\ Anses, Fougères Laboratory, Scientific Support Unit, Fougères, France
}

\begin{abstract}
This study describes a novel validation procedure of real-time PCR based on accuracy profile to estimate bacterial concentrations in fecal samples. To assess the performance of the method, measurements of axenic fecal samples spiked with a measured quantity of known bacterial species (Bacteroides fragilis, Bifidobacterium adolescentis, Enterococcus faecium, and Escherichia coli) were performed under repeatability and intermediate precision conditions. Data collected were used to compute a tolerance interval that was compared to a defined acceptance interval. It is concluded that the method is valid and relevant for the studied validation range of 8.20-10.24 and 7.43-9.47 $\log _{10} \mathrm{CFU} / \mathrm{g}$ of feces to ensure proper measurement of $B$. fragilis and $E$. coli, respectively. The LOQ is 8.20 and $7.43 \log _{10}$ CFU/g of feces. In contrast, the method is not valid for the quantification of $E$. faecium and $B$. adolescentis, but by applying a correction factor of $+0.63 \log _{10} \mathrm{CFU} / \mathrm{g}$, it can be considered valid for $E$. faecium. This correction is included in the final results. In conclusion, the accuracy profile is a statistical tool that is easy to use and totally adapted to validate real-time PCR.
\end{abstract}

$\mathrm{S}$ everal methods have been developed to numerate bacteria in biological and environmental samples; those for foodborne pathogens have been reviewed by Hoorfar (1). Sophisticated methods of molecular analysis of feces are being used to identify species and enumerate bacteria $(2,3)$. Molecular analysis can offer various advantages over cultural methods, including detection and enumeration of a wider range of uncultured microorganisms with greater sensitivity and specificity in environmental samples. However, feces consistency and components can make DNA extraction particularly difficult and the molecular analysis that follows, such as real-time PCR (qPCR), less efficient. Numerous DNA extraction methods, including commercial kits and homemade protocols, have been developed and used to determine bacterial population levels in several studies (4-7). However, only a few publications have fully demonstrated the effectiveness of their methods through

Received September 17, 2013. Accepted by AH November 13, 2013.

Corresponding author's e-mail: manuel.saint-cyr@anses.fr

DOI: $10.5740 /$ jaoacint.13-310 robust validation experiments (8). Most studies have evaluated the performance of quantification methods using samples spiked with nonrepresentative bacteria from the targeted bacterial groups or by testing only one bacterial concentration $(9,10)$.

The MIQE guidelines propose Minimum Information for Publication of Quantitative Real-Time PCR Experiments (MIQE) to ensure the relevance, accuracy, correct interpretation, and repeatability of the experiment (11). Although the MIQE guidelines offer technical support, there is a lack of complete validation experiments. In fact, real-time PCR is a quantification method; therefore, a validation process is required to decide whether the method is valid or not by calculating performance characteristics such as trueness, precision, recovery, range of application, LOD, LOQ, specificity, and selectivity (12). In addition, the goal of an analytical method is to fit-for-purpose, i.e., produce results that reflect the contents of samples with acceptable accuracy. This accuracy needs to assess trueness and precision simultaneously, i.e., to measure the total error that is used to determine the accuracy profile $(13,14)$. Therefore, the accuracy profile is a possible decision-making graphical tool to decide whether an experimental procedure is valid, and its use has been widely discussed for physicochemical methods in previous published works $(12,15,16)$. In 2009, Feinberg et al. (17) used this approach to validate an alternative method for counting bacteria. It was also recommended in French standard XP-U47600-2 (18).

Here, we present a novel approach that allows a statistical validation of real-time PCR experiments. This validation procedure uses the accuracy profile applied to the quantification of bacterial concentrations in fecal samples by real-time PCR. The method includes DNA extraction from feces and the amplification of target Gram-negative and Gram-positive bacterial species.

\section{Materials and Methods}

\section{Bacterial Strains and Growth Conditions}

Bacterial type strains were obtained from the Biological Resource Center of the Institut Pasteur (CRBIP, Paris, France) and are presented in Table 1.

All strains were inoculated into tryptic soy broth and thioglycollate broth with resazurine for aerobic and anaerobic bacteria, respectively. Pure cultures were incubated at $37^{\circ} \mathrm{C}$ in an aerobic or anaerobic atmosphere $\left(10 \% \mathrm{H}_{2}, 10 \% \mathrm{CO}_{2}, 80 \%\right.$ $\mathrm{N}_{2}$ ) for $24-48 \mathrm{~h}$. The total number of CFUs of each culture, 
Table 1. Type strains, oligonucleotide primers and probes used in this assay

\begin{tabular}{|c|c|c|c|c|}
\hline Target organism $^{a}$ & Type strain & Primer and probe & Sequence $5^{\prime}-3^{\prime}$ & References \\
\hline \multirow[t]{3}{*}{ Bact-Prev } & Bacteroides fragilis CIP 77.16 & F_Bacter 11 & CCTWCGATG GAT AGGGGT T & (9) \\
\hline & & F_Bacter 08 & CAC GCTACTTGGCTGGTT CAG & \\
\hline & & P_Bac303 & VIC-AAGGTC CCC CAC ATT G & \\
\hline \multirow[t]{3}{*}{ Bifid } & Bifidobacterium adolescentis CIP 64.59 & F_Bifid 09c & CGGGTGAGTAATGCGTGA CC & (9) \\
\hline & & R_Bifid 06 & TGA TAG GACGCGACCCCA & \\
\hline & & P_Bifid & 6FAM-CTC CTGGAAACGGGT G & \\
\hline \multirow[t]{2}{*}{ Entero } & Enterococcus faecium CIP 103014 & F_Entero & CCC TTATTGTTAGTTGCCATC ATT & $(30)$ \\
\hline & & R_Entero & ACT CGTTGT ACT TCC CAT TGT & \\
\hline \multirow[t]{2}{*}{ E. coli } & Escherichia coli CIP 54.8 & E.coli F & CAT GCCGCGTGTATGAAG AA & (31) \\
\hline & & E.coli R & CGGGTAACGTCAATGAGCAAA & \\
\hline
\end{tabular}

a Bact-Prev = Bacteroides-Prevotella group; Bifid = Genus Bifidobacterium; Entero = Genus Enterococcus; E. coli = Escherichia coli.

was determined by plating $100 \mu \mathrm{L}$ of the appropriate 10 -fold dilution series on trypticase soy agar with $10 \%$ sheep blood, and on Schaedler agar with vitamin $\mathrm{K}_{1}$ and $5 \%$ sheep blood (BD Diagnostic Systems, Le Pont de Claix, France) for aerobic and anaerobic bacteria, respectively.

\section{Fecal Samples}

All animal procedures were carried out in strict accordance with the recommendations of the French Ministry of Agriculture. The protocol was approved by Anses's Committee for Ethical Standards and performed in our approved animal breeding facility (Permit No. D35-137-26).

Fecal samples were obtained from rats (Charles River, Saint Germain sur l'Arbresle, France) housed in a sterile isolator. Within $2 \mathrm{~h}$ after collection, samples were stored at $-80^{\circ} \mathrm{C}$ until further analysis.

\section{DNA Extractions}

Genomic DNA from fresh bacterial cultures at exponential phase was extracted using Wizard Genomic DNA Purification
Kit (Promega, Charbonnières Les Bains, France) according to the manufacturer's instructions. Extracted DNA was quantified using the BioSpec-nano spectrophotometer (Shimadzu Scientific Instruments, Columbia, MD).

Fecal DNA was extracted from $0.2 \mathrm{~g}$ of fecal material using the G'NOME $^{\circledR}$ kit (BIO 101, La Jolla, CA) with modifications as provided by Furet et al. (9). Briefly, fecal samples were homogenized in $480 \mu \mathrm{L}$ of the supplied cell suspension solution. A $100 \mu \mathrm{L}$ amount of cell lysis/denaturing solution (G'NOME kit) and $50 \mu \mathrm{L}$ of RNase mix (G'NOME kit) were then added, and the samples were incubated at $55^{\circ} \mathrm{C}$ for 30 min with shaking at $900 \mathrm{rpm}$. A $25 \mu \mathrm{L}$ amount of protease mix (G'NOME kit) was added to the RNase-treated samples, which were then incubated at $55^{\circ} \mathrm{C}$ for $2 \mathrm{~h}$ with shaking at $900 \mathrm{rpm}$. To improve cellular lysis, $750 \mu \mathrm{L}$ of $0.1 \mathrm{~mm}$ diameter zirconia/silica beads (Biospec, Bartlesville, CA) was added, and agitation was carried out at maximum speed for $10 \mathrm{~min}$ in a Bead-Beater MM200 (Retsch, Haan, Germany). Polyvinylpolypyrrolidone (15 mg) (Sigma Aldrich, Saint-Quentin Fallavier, France) was added to ensure removal of polyphenol contamination that could inhibit subsequent qPCR reactions.

Samples were vortexed and centrifuged at $20000 \mathrm{~g}$ for

Table 2. Results $\left(\log _{10} \mathrm{CFU} / \mathrm{g}\right)$ of the validation experiment

\begin{tabular}{|c|c|c|c|c|c|c|c|}
\hline \multirow[b]{2}{*}{ Bacteria } & \multirow[b]{2}{*}{ Reference concn } & \multirow[b]{2}{*}{ Avg. recovered concn } & \multirow[b]{2}{*}{ Bias } & \multirow[b]{2}{*}{ Intermediate precision $\left(s_{I P}\right)$} & \multirow[b]{2}{*}{ Repeatability $\left(s_{r}\right)$} & \multicolumn{2}{|c|}{$\beta-\mathrm{ETI}^{a}$} \\
\hline & & & & & & Lower limit & Upper limit \\
\hline \multirow[t]{3}{*}{ E. coli } & 7.43 & 7.42 & -0.01 & 0.20 & 0.14 & -0.41 & 0.39 \\
\hline & 8.45 & 8.42 & -0.02 & 0.19 & 0.11 & -0.40 & 0.35 \\
\hline & 9.47 & 9.23 & -0.24 & 0.12 & 0.12 & -0.47 & 0.00 \\
\hline \multirow[t]{3}{*}{ B. fragilis } & 8.20 & 8.40 & 0.20 & 0.13 & 0.09 & -0.06 & 0.47 \\
\hline & 9.21 & 9.28 & 0.07 & 0.15 & 0.13 & -0.23 & 0.36 \\
\hline & 10.24 & 10.11 & -0.13 & 0.12 & 0.10 & -0.36 & 0.10 \\
\hline \multirow[t]{3}{*}{ B. adolescentis } & 8.18 & 7.80 & -0.38 & 0.24 & 0.24 & -0.86 & 0.10 \\
\hline & 9.19 & 8.75 & -0.44 & 0.31 & 0.20 & -1.07 & 0.18 \\
\hline & 10.22 & 9.45 & -0.77 & 0.28 & 0.08 & -1.33 & -0.20 \\
\hline \multirow[t]{3}{*}{ E. faecium } & 7.21 & 6.63 & -0.58 & 0.19 & 0.19 & -0.96 & -0.20 \\
\hline & 8.22 & 7.60 & -0.62 & 0.21 & 0.14 & -1.04 & -0.20 \\
\hline & 9.25 & 8.55 & -0.70 & 0.11 & 0.10 & -0.91 & -0.48 \\
\hline
\end{tabular}

\footnotetext{
a $\beta-\mathrm{ETI}=\beta$ expectation tolerance interval.
} 

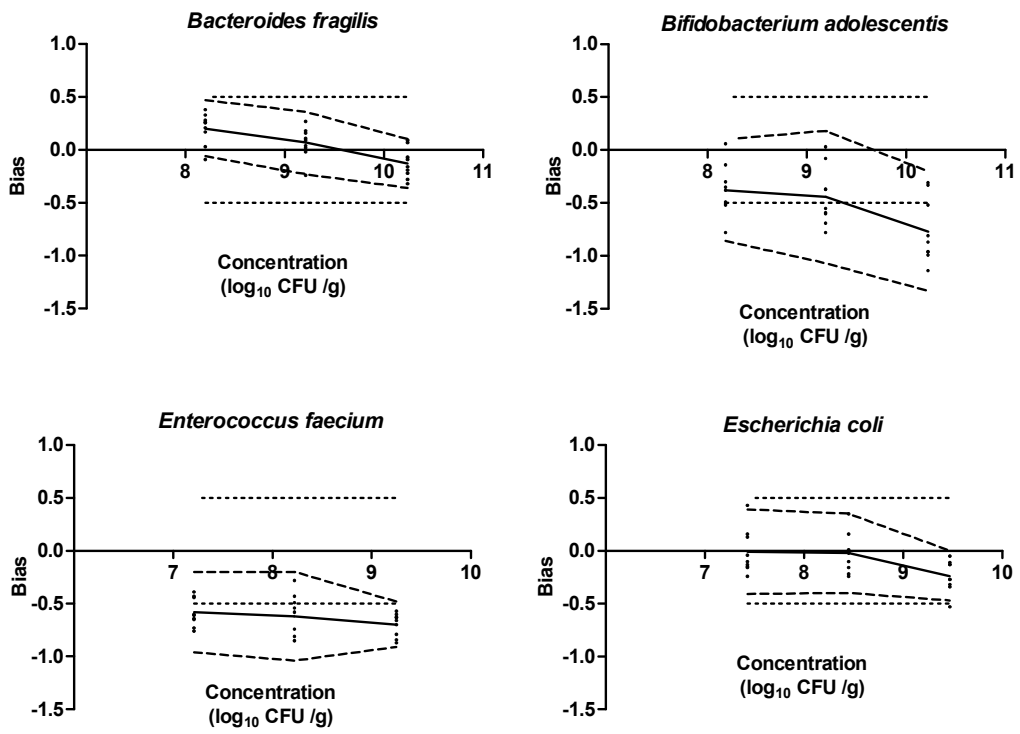

Figure 1. Accuracy profiles of the qPCR for B. fragilis, B. adolescentis, E. faecium, and $E$. coli for $\beta=95 \%$ and $\lambda=0.5$ log ${ }_{10}$ CFU/g. The black line represents the bias of the method; dashed lines are the tolerance limits that define the $95 \%$ tolerance interval around the bias, i.e., the precision of the method; black points are raw data; dotted lines are the acceptance limits that show the validation area.

$3 \mathrm{~min}$, and the supernatant was recovered in a clean $2 \mathrm{~mL}$ microcentrifuge tube. The remaining pellet was washed with $400 \mu \mathrm{L}$ TENP (50 mM Tris, pH 8; 20 mM EDTA, pH 8; 100 mM $\mathrm{NaCl} ; 1 \%$ polyvinylpolypyrrolidone) and centrifuged at $20000 \mathrm{~g}$ for $3 \mathrm{~min}$. The washing step was repeated twice more, and the resulting supernatants were pooled $(1.5 \mathrm{~mL})$. Half of the supernatant $(750 \mu \mathrm{L})$ was precipitated by addition of $1 \mathrm{~mL}$ of icecold isopropanol, then stored at $-20^{\circ} \mathrm{C}$ for $10 \mathrm{~min}$ and centrifuged at $20000 \mathrm{~g}$ for $10 \mathrm{~min}$. The tube was drained on clean absorbent paper, and the pellet was resuspended in $400 \mu \mathrm{L}$ of ultrapure water plus $100 \mu \mathrm{L}$ of salt-out mixture (G'NOME kit) and incubated at $4{ }^{\circ} \mathrm{C}$ for $10 \mathrm{~min}$. Samples were spun for $10 \mathrm{~min}$ at maximum speed, and the supernatant containing the DNA was transferred to a clean $2 \mathrm{~mL}$ microcentrifuge tube. DNA was precipitated with $1.5 \mathrm{~mL}$ of ice-cold $100 \%$ ethanol at room temperature for $5 \mathrm{~min}$ followed by centrifugation at $20000 \mathrm{~g}$ for $5 \mathrm{~min}$. The DNA pellet was washed with $1 \mathrm{~mL}$ of room temperature $70 \%$ ethanol. After the pellet was air-dried, the DNA was resuspended in $150 \mu \mathrm{L}$ of Tris EDTA buffer. The extracted DNA was stored at $-20^{\circ} \mathrm{C}$ until analysis.

\section{Oligonucleotide Primers and Probes}

Primers and probes used in this study are presented in Table 1. TaqMan qPCR was adapted to quantify the BacteroidesPrevotella group and the genus Bifidobacterium. Real-time qPCR using SYBR ${ }^{\circledR}$ Green was performed for $E$. coli and the genus Enterococcus. Primer and probe specificities were previously assessed by Furet et al. (9). The TaqMan probes were synthesized by Life Technologies (Saint Aubin, France). The primers were purchased from Sigma Aldrich.

\section{Real-Time PCR Conditions}

PCR was performed in $25 \mu \mathrm{L}$ PCR volumes containing $15 \mu \mathrm{L}$ Power SYBR Green PCR Master Mix 2X (Life Technologies) or TaqMan Universal PCR 2 (Life Technologies), $0.20 \mu \mathrm{M}$ of each primer, $0.25 \mu \mathrm{M}$ of each probe, and $10 \mu \mathrm{L}$ of template DNA at the appropriate dilution i.e., to fall within the range covered by the calibration curve and avoid inhibition. Natural Multiplate Low-Profile 96-Well Unskirted PCR Plates and a Chromo4 LightCycler were used (Bio-Rad, Marnes-La-Coquette, France). The cycling program included a $10 \mathrm{~min}$ incubation at $95^{\circ} \mathrm{C}$ followed by 40 cycles consisting of $95^{\circ} \mathrm{C}$ for $30 \mathrm{~s}$, and $60^{\circ} \mathrm{C}$ for $1 \mathrm{~min}$. For SYBR-Green amplifications, to improve amplification specificity, a melting curve analysis of the PCR products was performed by ramping the temperature to $95^{\circ} \mathrm{C}$ for $10 \mathrm{~s}$ and back to $50^{\circ} \mathrm{C}$ for $15 \mathrm{~s}$ followed by incremental increases of $0.5^{\circ} \mathrm{C} \mathrm{s}^{-1}$ up to $95^{\circ} \mathrm{C}$. The cycle threshold $(\mathrm{Ct})$, i.e., the number of PCR cycles necessary to reach the threshold fluorescence level, was manually determined for each run by the user. All samples were analyzed in duplicate.

\section{PCR Setup Controls}

Multiple Non Template Controls (NTC) were included in every assay, and amplification of all NTC wells invalidated the entire $\mathrm{qPCR}$ run, leading to a repeat run.

\section{Design of Validation Experiment}

Calibration standards.-Genomic DNA from the different pure cultures was used to prepare 10-fold dilution series from $0.1 \log _{10}$ to $8 \log _{10} \mathrm{CFU}$ equivalent. Sterile water $(15 \mu \mathrm{L})$ was used as a negative control. A standard curve for each type strain was generated by plotting the $\mathrm{Ct}$ against the logarithm of bacterial quantity ( $\log _{10}$ CFU equivalent).

Validation standards.-To validate the method, several fecal samples from germ-free rats were spiked with a measured quantity of known bacterial species. Briefly, pure cultures of type strains were used to spike $200 \mathrm{mg}$ of bacteria-free fecal samples in triplicate at three different concentration levels, ranging from 7.21 to $10.24 \log _{10} \mathrm{CFU}$ equivalent/g of fresh feces corresponding to amounts ranging from 6.51 to $9.54 \log _{10} \mathrm{CFU}$ equivalent, in three 


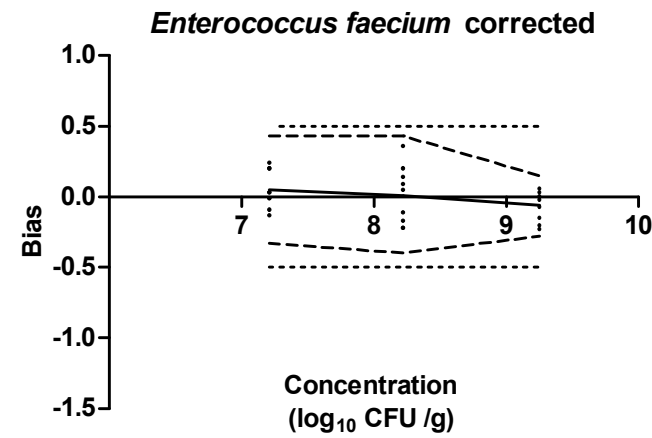

Figure 2. Corrected accuracy profile for $E$. faecium after subtracting the additive bias. The black line represents the bias of the method; dashed lines are the tolerance limits that define the $95 \%$ tolerance interval around the bias, i.e., the precision of the method, black points are raw data; dotted lines are the acceptance limits that show the validation area.

independent experiments. As a negative control, axenic feces were spiked with sterile water. To mimic the experimental design, the feces were mixed with the four bacteria simultaneously, and the spiked samples were stored at $-80^{\circ} \mathrm{C}$ until extraction and realtime PCR analysis.

Total DNA of 27 spiked fecal samples and three negative controls were extracted as described above. Then, the resulting levels of the different bacteria were assessed by real-time qPCR using species-specific 16S rRNA gene primers (Table 1). The number of bacteria cells was determined by plotting the $\mathrm{Ct}$ obtained against the standard curve. For the highest concentrations expected to fall outside the range covered by the standard curve, an appropriate dilution was applied.

Validation samples.-To illustrate the quantification method, samples from a pilot study on the effect of a fourth-generation cephalosporin on different types of fecal bacteria were used. Briefly, four germ-free male rats, housed individually in a sterile isolator, were inoculated with fresh fecal swine flora. After implantation and stabilization, the rats received a single dose of subcutaneous cefquinome treatment (Cobactan; Intervet, Beaucouze, France) at $10 \mathrm{mg} / \mathrm{kg}$ for 4 days from Day 0 to Day 4 following fecal sampling. Fecal samples were collected before the treatment (Day 0), during the treatment at Days 1, 2, 3, and 5 after the end of treatment. Microbiota evolution was measured by $\mathrm{qPCR}$, as described above.

\section{Accuracy Profile Procedure}

The accuracy profile, represented by a two-sided $\beta$ expectation tolerance interval $(\beta$-ETI), was calculated for each concentration level from the results of the validation experiments. We defined the acceptability limits $(\lambda)$ at $\pm 0.5 \log _{10}$ unit in accordance with the French standard $(17,18)$. The risk was set at $5 \%$ supporting that $95 \%(\beta)$ of future measurements would fall within the acceptability limits.

The complete theory and calculation of accuracy profiles are described in references 13,14 , and 19, and a fully developed application is presented for microbiological methods in references 17 and 20 . The procedure reported here is simplified and adapted to molecular methods; the different data obtained were analyzed with a Microsoft Excel worksheet based on French standard XP U47-600-2 (18). The calculation procedure can be summarized as the following sequence of operations: Define the acceptability limits for the method. Collect $\log _{10}$ CFU equivalent/g of fresh feces obtained. For each concentration level, calculate the intermediate precision $\left(s_{I P}\right)$ using Equation 1:

$$
s_{I P}=\sqrt{s_{B}^{2}+s_{r}^{2}}
$$

where $s_{r}{ }^{2}$ represents the within-series variance (repeatability variance) and $s_{B}{ }^{2}$ the between-series variance. For each level, compute $\overline{\bar{x}}$ the average of measurements (recovered concentrations) and calculate the absolute bias according to Equation 2:

$$
\overline{\bar{x}}-T
$$

where $T$ is the reference concentration at each level. For each level, calculate the limits of the $\beta$-ETI according to Equation 3:

$$
\overline{\bar{x}} \pm k_{M} \times s_{I P}
$$

where $k_{M}$ represents a coverage factor established at 2 in the French standard XP U47-600-2 (18). For each level, compute the difference between the $\beta$-ETI limits and the reference concentration $T$ according to Equation 4:

$$
\left[\overline{\bar{x}} \mp k_{M} \times s_{I P}\right]-T
$$

\begin{tabular}{|c|c|c|c|c|c|}
\hline \multirow[b]{3}{*}{ Bacterial groups } & \multicolumn{5}{|c|}{ Experimental period, in days (d) } \\
\hline & \multicolumn{4}{|c|}{ Treatment } & \multirow{2}{*}{$\begin{array}{c}\text { Post } \\
d 5\end{array}$} \\
\hline & d0 & $\mathrm{d} 1$ & d2 & d3 & \\
\hline Bact-Prev & $10.3 \pm 0.23$ & $10.3 \pm 0.07$ & $10.2 \pm 0.23$ & $10.2 \pm 0.15$ & $10.2 \pm 0.24$ \\
\hline Bifid & $<L_{O Q}^{(a)}$ & $<\operatorname{LOD}^{(\mathrm{b})}$ & $<\operatorname{LOD}^{(b)}$ & $<\operatorname{LOD}^{(\mathrm{b})}$ & $<\mathrm{LOQ}^{(\mathrm{a})}$ \\
\hline Entero & $10.0 \pm 0.76$ & $9.2 \pm 0.42$ & $8.9 \pm 0.61^{*}$ & $8.7 \pm 0.26^{*}$ & $9.0 \pm 0.43$ \\
\hline E. coli & $8.8 \pm 0.36$ & $<\mathrm{LOQ}^{(\mathrm{c})}$ & $<\mathrm{LOQ}^{(\mathrm{c})}$ & $<\mathrm{LOQ}^{(\mathrm{c})}$ & $8.6 \pm 0.43$ \\
\hline
\end{tabular}

Generate a graphical representation of calculated results as

Table 3. Quantification of dominant and subdominant bacteria in fecal microbiota ${ }^{a}$

a Results obtained by qPCR were expressed as the mean of the $\log _{10}$ value $(n=4) \pm$ SD of $\log _{10}$ CFU/g; Bact-Prev $=$ Bacteroides-Prevotella group; Bifid = Genus Bifidobacterium; Entero = Genus Enterococcus; E. coli $=$ Escherichia coli; (a) Bifidobacterium LOQ $=8.18$ log $10 \mathrm{CFU} / \mathrm{g}$; (b) $\mathrm{LOD}=5 \log _{10} \mathrm{CFU} / \mathrm{g}$; (c) $E$. coli LOQ $=7.43 \log _{10} \mathrm{CFU} / \mathrm{g}$; * indicates a significant difference at $P<0.05$ in comparison to d0. 


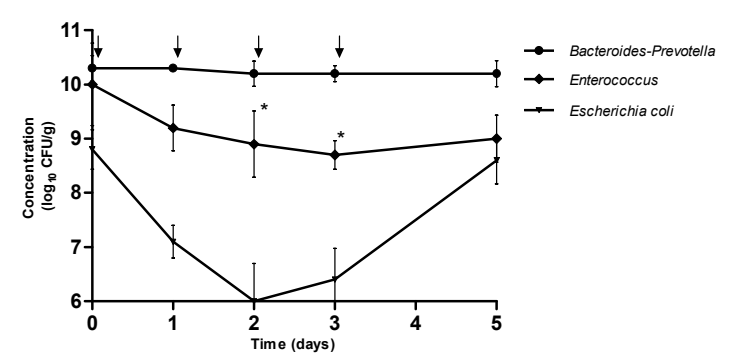

Figure 3. Time course evolution of gut microbiota during cefquinome treatment. Arrows indicate cefquinome administration; asterisk indicates a significant difference at $P<0.05$ in comparison to do.

follows: on the horizontal (x) axis, plot the reference concentrations $T$ in $\log _{10} \mathrm{CFU} / \mathrm{g}$. On the vertical (y) axis, simultaneously plot at each level the bias (Equation 2), the acceptability limits $(\lambda)$, and the limits of the $\beta$-ETI (Equation 4), all expressed in in $\log _{10}$ $\mathrm{CFU} / \mathrm{g}$.

\section{Statistical Analysis of the Pilot Study}

The data are presented as the $\log _{10}$ CFU equivalent/g of fresh feces $\left(\log _{10} \mathrm{CFU} / \mathrm{g}\right)$. Statistical analysis was performed with SYSTAT V.13 (Systat Software, Chicago, IL). Bacterial levels were compared using analysis of variance, followed by Dunnett's Multiple Comparison test to compare each sampling time during and after the treatment to the sampling time before the treatment (control). $P$ values $<0.05$ were considered statistically significant.

\section{Results and Discussion}

This validation study is the first application of an accuracy profile to qPCR for the quantification of four bacterial species from intestinal microbiota.

\section{Validation Experiment}

Table 2 shows the main performance parameters such as average recovered concentrations, repeatability, intermediate precision, absolute bias, and the tolerance intervals for each target bacteria. In Table 2, trueness is represented by the absolute bias, and precision is symbolized by the lower and upper tolerance limits ( $\beta$-ETI) calculated with intermediate precision including repeatability.

Generally, bias showed great variability depending on the bacterial species and concentration levels. For E. coli and $B$. fragilis, biases ranged from -0.01 to -0.24 and -0.13 to $0.20 \log _{10} \mathrm{CFU} / \mathrm{g}$, respectively. In contrast, the biases for E. faecium and B. adolescentis were higher, ranging from -0.58 to -0.70 and -0.77 to $-0.38 \log _{10} \mathrm{CFU} / \mathrm{g}$, respectively. These results indicated that the trueness of the method for E. faecium and $B$. adolescentis did not satisfy the acceptability criteria conditions of $\pm 0.5 \log _{10} \mathrm{CFU} / \mathrm{g}$. The tolerance interval values were largely above the $\pm 0.5 \log _{10} \mathrm{CFU} / \mathrm{g}$ acceptability limits for B. adolescentis and E. faecium.

\section{Accuracy Profiles}

In this study, we assessed the performance of a quantification method using the accuracy profile procedure in the scope of molecular biology. Several papers describe the mathematical relation for standard curves, but they do not assess the performance of the method in terms of bias and precision (21-24). The accuracy profile enables characterization of variability under defined conditions. In our study, measurements were performed under repeatability and intermediate precision conditions and were then used to compute a tolerance interval, i.e., an interval within which $95 \%$ of future measurements will be expected to fall. When the accuracy profile interval was compared to an acceptability interval defined by the acceptability limits, it was possible to draw conclusions about the validity of the method (18). This issue is in line with the current revision work of the standard ISO 16140:2003 (25), which strives to include acceptability criteria for the analytical performance characteristics as reviewed by Lombard and Leclercq (26).

From the data in Table 2, the average recovered concentrations and the tolerance intervals were used to compute the four accuracy profiles that are shown in Figure 1. When considering the profiles for the quantification of E. coli and B. fragilis, the tolerance intervals were within the acceptability limits of $\pm 0.5 \log _{10} \mathrm{CFU} / \mathrm{g}$. It can therefore be concluded that the method is valid and relevant for the studied validation range of 8.20-10.24 and 7.43-9.47 $\log _{10} \mathrm{CFU} / \mathrm{g}$ to ensure proper measurement of B. fragilis and E. coli, respectively. In this case, the LOQ was equal to the lowest limit of the validation domain, i.e., 8.20 and $7.43 \log _{10} \mathrm{CFU} / \mathrm{g}$.

In contrast, for E. faecium and B. adolescentis, a part of the tolerance intervals is excluded from the acceptability limits, as demonstrated in Figure 1. Consequently, the method is not valid for the quantification of these bacteria. However, for E. faecium, the absolute bias is excluded from the acceptability limits but is constant throughout the range level. This type of accuracy profile was also described for analytical methods in chemistry and was analyzed in the usual manner using a correction factor $(16,19)$. In fact, error is mainly linked to a systematic error which was assessed and determined on accuracy profile. In our case, the correction factor was estimated at $+0.63 \log _{10} \mathrm{CFU} / \mathrm{g}$, corresponding to a mean value of the bias. All concentrations were adjusted, and the accuracy profile was recalculated and is shown in Figure 2. It was clearly demonstrated that after correction, the bias was close to zero and the tolerance intervals were within the acceptability limits. Consequently, the method can also be considered valid for E. faecium, and the correction will be taken into account in the expression of the final results.

On the other hand, correction could not be used for B. adolescentis because the bias was not constant and the precision was highly variable throughout the range of tested concentrations. Although the method was not valid for quantification, it could be used for detection of the genus Bifidobacterium.

In conclusion, we validated the method for three of the four target bacteria, i.e., B. fragilis, E. coli, and E. faecium, by using the accuracy profile. Knowledge of the accuracy ensures that $95 \%$ of future measurements will be in the validated interval concentration. For Gram-positive bacteria E. faecium and B. adolescentis, the bias observed could be assumed to the cell wall difference in extraction efficiency. Previous studies have shown that observed microbial composition is mainly affected by the efficiency of cell lysis $(5,6,27)$. However, for E. faecium, the 
accuracy profile allows correct estimate of the true concentration of this bacterium by applying a correction factor.

\section{Time Course Evolution of Gut Microbiota During Cefquinome Treatment}

To illustrate the quantification method, we investigated the effect of an antibiotic treatment on the intestinal microbiota balance by assessing the time course evolution of fecal bacterial populations using qPCR. Table 3 and Figure 3 illustrate the results obtained with four target bacterial groups. In our study, cefquinome showed a broad spectrum of activity typical for fourth-generation cephalosporins.

The high in vivo activity of cefquinome against the genus Bifidobacterium was supported by the absence of detection during the treatment period (28). Bifidobacteria were detected before and after the treatment, while during cefquinome administration from Day 1 to Day 3, Bifidobacterium levels dropped below the LOD ( $\left.5 \log _{10} \mathrm{CFU} / \mathrm{g}\right)$.

The Bacteroides-Prevotella group levels were not significantly different $(P>0.05)$ and remained stable during the antibiotic treatment at an average level of $10.2 \log _{10} \mathrm{CFU} / \mathrm{g}$. We can conclude that cefquinome had no effect on the Bacteroides-Prevotella group, as was shown by Limbert et al. (28), who found that 11 of the 14 tested strains were resistant to cefquinome at an in vitro concentration higher than $100 \mu \mathrm{g} / \mathrm{mL}$ (28).

Cefquinome demonstrated moderate activity on the genus Enterococcus. These results are supported by a significant decrease of concentration observed from Day 2 to Day 3 $(P<0.05)$, as described in an earlier survey (13).

The concentrations of $E$. coli in feces drastically decreased by $2 \log _{10}$ below the LOQ from Day 1 to Day 3 of the treatment. After the end of treatment (Day 5), the concentration of E. coli increased to above the LOQ and returned to a basal level of $8.6 \log _{10} \mathrm{CFU} / \mathrm{g}$. Considering that the values obtained were below the LOQ, the data cannot be statistically analyzed. However, the observations highlighted that $E$. coli was strongly affected by cefquinome treatment as previously described (29).

\section{Conclusions}

The accuracy profile is easy to use and fully suited to validation of real-time PCR in a range of concentrations and for any type of ecosystem sample (soil, feces). In addition, the use of accuracy profile could be extended to other molecular methods dealing with bacteria quantification, but some adjustments could be required such as acceptability limits and fit-for-purpose.

The method was validated for both DNA extraction and molecular quantification with fecal target bacteria and therefore can be recommended for all studies dealing with the quantification of bacteria in feces. Based on this, we are confident that the use of the accuracy profile for the validation procedure allowed us to highlight changes in intestinal microbiota.

\section{Acknowledgments}

We thank Jacqueline Manceau for validation support, and Jean-Guy Rolland, Fougéres Laboratory, Scientific Support Unit, Fougéres, France, for technical support.

\section{References}

(1) Hoorfar, J. (2011) APMIS 119, 1-24. http://dx.doi.org/10.1111/ j.1600-0463.2011.02767.x

(2) Eckburg, P.B., Bik, E.M., Bernstein, C.N., Purdom, E., Dethlefsen, L., Sargent, M., Gill, S.R., Nelson, K.E., \& Relman, D.A. (2005) Science 308, 1635-1638. http://dx.doi.org/10.1126/ science.1110591

(3) Zwielehner, J., Lassl, C., Hippe, B., Pointner, A., Switzeny, O.J., Remely, M., Kitzweger, E., Ruckser, R., \& Haslberger, A.G. (2011) PLoS ONE 6, e28654. http://dx.doi.org/10.1371/journal. pone. 0028654

(4) McOrist, A.L., Jackson, M., \& Bird, A.R. (2002) J. Microbiol. Methods 50, 131-139. http://dx.doi.org/10.1016/S01677012(02)00018-0

(5) Salonen, A., Nikkilä, J., Jalanka-Tuovinen, J., Immonen, O., Rajilic-Stojanovic, M., Kekkonen, R.A., Palva, A., \& de Vos, W.M. (2010) J. Microbiol. Methods 81, 127-134. http://dx.doi. org/10.1016/j.mimet.2010.02.007

(6) Yuan, S., Cohen, D.B., Ravel, J., Abdo, Z., \& Forney, L.J. (2012) PLoS ONE 7, e33865. http://dx.doi.org/10.1371/journal. pone. 0033865

(7) Tang, J.N., Zeng, Z.G., Wang, H.N., Yang, T., Zhang, P.J., Li, Y.L., Zhang, A.Y., Fan, W.Q., Zhang, Y., Yang, X., Zhao, S.J., Tian, G.B., \& Zou, L.K. (2008) J. Microbiol. Methods 75, 432-436. http://dx.doi.org/10.1016/j.mimet.2008.07.014

(8) Leblanc-Maridor, M., Garénaux, A., Beaudeau, F., Chidaine, B., Seegers, H., Denis, M., \& Belloc, C. (2011) J. Microbiol. Methods 85, 53-61. http://dx.doi.org/10.1016/j.mimet.2011.01.013

(9) Furet, J.-P., Firmesse, O., Gourmelon, M., Bridonneau, C., Tap, J., Mondot, S., Doré, J., \& Corthier, G. (2009) FEMS Microbiol. Ecol. 68, 351-362. http://dx.doi.org/10.1111/j.15746941.2009.00671.x

(10) Wang, I.K., Lai, H.C., Yu, C.J., Liang, C.C., Chang, C.T., Kuo, H.L., Yang, Y.F., Lin, C.C., Lin, H.H., Liu, Y.L., Chang, Y.C., Wu, Y.Y., Chen, C.H., Li, C.Y., Chuang, F.R., Huang, C.C., Lin, C.H., \& Lin, H.C. (2012) Appl. Environ. Microbiol. 78, 1107-1112. http://dx.doi.org/10.1128/AEM.05605-11

(11) Bustin, S., Beaulieu, J.-F., Huggett, J., Jaggi, R., Kibenge, F., Olsvik, P., Penning, L., \& Toegel, S. (2010) BMC Molecular Biology 11, 74. http://dx.doi.org/10.1186/1471-2199-11-74

(12) Feinberg, M. (2007) J. Chromatogr. A 1158, 174-183. http:// dx.doi.org/10.1016/j.chroma.2007.02.021

(13) Hubert, P., Nguyen-Huu, J.J., Boulanger, B., Chapuzet, E., Chiap, P., Cohen, N., Compagnon, P.A., Dewé, W., Feinberg, M., Lallier, M., Laurentie, M., Mercier, N., Muzard, G., Nivet, C., Valat, L., \& Rozet, E. (2007) J. Pharm. Biomed. Anal. 45, 70-81. http:// dx.doi.org/10.1016/j.jpba.2007.06.013

(14) Hubert, P., Nguyen-Huu, J.J., Boulanger, B., Chapuzet, E., Cohen, N., Compagnon, P.A., Dewé, W., Feinberg, M., Laurentie, M., Mercier, N., Muzard, G., Valat, L., \& Rozet, E. (2007) J. Pharm. Biomed. Anal. 45, 82-96. http://dx.doi.org/10.1016/j. jpba.2007.06.032

(15) Chéneau, E., Henri, J., Pirotais, Y., Abjean, J.-P., Roudaut, B., Sanders, P., \& Laurentie, M. (2007) J. Chromatogr. B 850, 15-23. http://dx.doi.org/10.1016/j.jchromb.2006.10.072

(16) Feinberg, M., San-Redon, J., \& Assié, A. (2009) J. Chromatogr. B 877, 2388-2395. http://dx.doi.org/10.1016/j.jchromb.2008.10.004

(17) Feinberg, M., Sohier, D., \& David, J.-F. (2009) J. AOAC Int. 92 , 527-537

(18) AFNOR XP U47-600-2:2011 (2011) Animal Health Analysis Methods-PCR - Part 2: Requirements and Recommendations for the Development and the Validation of Veterinary PCR, Cedex, France

(19) Hubert, P., Nguyen-Huu, J.J., Boulanger, B., Chapuzet, E., Cohen, N., Compagnon, P.A., Dewé, W., Feinberg, M., Laurentie, M., Mercier, N., Muzard, G., Valat, L., \& Rozet, E. (2008) J. 
Pharm. Biomed. Anal. 48, 760-771. http://dx.doi.org/10.1016/j. jpba.2008.07.018

(20) Boubetra, A., Le Nestour, F., Allaert, C., \& Feinberg, M. (2011) Appl. Environ. Microbiol. 77, 3360-3367. http://dx.doi. org/10.1128/AEM.00020-11

(21) Bar, T., Kubista, M., \& Tichopad, A. (2012) Nucleic Acids Res. 40, 1395-1406. http://dx.doi.org/10.1093/nar/gkr778

(22) Chandelier, A., Ivors, K., Garbelotto, M., Zini, J., Laurent, F., \& Cavelier, M. (2006) Validation of a Real-Time PCR Method for the Detection of Phytophthora ramorum, Blackwell, Oxford, ROYAUME-UNI

(23) Liu, W., \& Saint, D.A. (2002) Biochem. Biophys. Res. Commun. 294, 347-353. http://dx.doi.org/10.1016/S0006-291X(02)00478-3

(24) Rutledge, R.G., \& Côté, C. (2003) Nucleic Acids Res. 31, e93. http://dx.doi.org/10.1093/nar/gng093

(25) ISO 16140:2003 (2003) Microbiology of Food and Animal Feeding Stuffs-Protocol for the Validation of Alternative Methods, International Organization for Standardization, Geneva, Switzerland
(26) Lombard, B., \& Leclercq, A. (2011) Food Anal. Meth. 4, 163-172. http://dx.doi.org/10.1007/s12161-010-9154-4

(27) Scupham, A.J., Jones, J.A., \& Wesley, I.V. (2007) J. Appl. Microbiol. 102, 401-409. http://dx.doi.org/10.1111/j.13652672.2006.03094.x

(28) Limbert, M., Isert, D., Klesel, N., Markus, A., Seeger, K., Seibert, G., \& Schrinner, E. (1991) Antimicrob. Agents Chemother. 35, 14-19. http://dx.doi.org/10.1128/AAC.35.1.14

(29) Thomas, E., Thomas, V., \& Wilhelm, C. (2006) Vet. Microbiol. 115, 140-147. http://dx.doi.org/10.1016/j.vetmic.2005.12.019

(30) Rinttilä, T., Kassinen, A., Malinen, E., Krogius, L., \& Palva, A. (2004) J. Appl. Microbiol. 97, 1166-1177. http://dx.doi. org/10.1111/j.1365-2672.2004.02409.x

(31) Huijsdens, X.W., Linskens, R.K., Mak, M., Meuwissen, S.G.M., Vandenbroucke-Grauls, C.M.J.E., \& Savelkoul, P.H.M. (2002) J. Clin. Microbiol. 40, 4423-4427. http://dx.doi.org/10.1128/ JCM.40.12.4423-4427.2002 